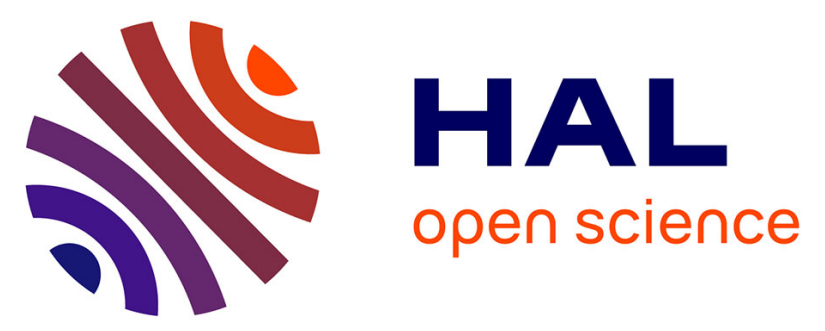

\title{
Severe HIV-associated aphthous stomatitis treated with etanercept
}

\author{
V. Rzepecki, J. Reynes, V. Le Moing, P. Braquet, V. Faucherre, L. Lohan, D. \\ Morquin, A. Makinson
}

\section{- To cite this version:}

V. Rzepecki, J. Reynes, V. Le Moing, P. Braquet, V. Faucherre, et al.. Severe HIV-associated aphthous stomatitis treated with etanercept. Médecine et Maladies Infectieuses, 2019, 49 (3), pp.219-220. 10.1016/j.medmal.2018.11.005 . hal-02594165

\section{HAL Id: hal-02594165 \\ https://hal.umontpellier.fr/hal-02594165}

Submitted on 22 Oct 2021

HAL is a multi-disciplinary open access archive for the deposit and dissemination of scientific research documents, whether they are published or not. The documents may come from teaching and research institutions in France or abroad, or from public or private research centers.
L'archive ouverte pluridisciplinaire HAL, est destinée au dépôt et à la diffusion de documents scientifiques de niveau recherche, publiés ou non, émanant des établissements d'enseignement et de recherche français ou étrangers, des laboratoires publics ou privés.

\section{다)(1) $(5$}

Distributed under a Creative Commons Attribution - NonCommerciall 4.0 International 
Severe HIV-associated aphthous stomatitis treated with etanercept Traitement par étanercept d'une aphtose buccale grave associée au VIH

V Rzepecki ${ }^{1}$, J Reynes ${ }^{1}$, V Le Moing ${ }^{1}$, P Braquet ${ }^{1}$, V Faucherre ${ }^{1}$, L Lohan ${ }^{2}$, D Morquin ${ }^{1}$, A Makinson*1

1. CHU de Montpellier, Maladies Infectieuses, Inserm U1175, Montpellier, France

2 CHU de Montpellier, Pharmacie, Montpellier, France

Corresponding author: A. Makinson (a-makinson@chu[-montpellier.fr)

Keywords: aphthous stomatitis, HIV, etanercept

Mots clés : aphtes, VIH, étanercept

\section{Funding}

This study has received no funding. Data was generated as part of the routine work in the Department of Infectious Diseases of the University Hospital of Montpellier, France.

\section{Declaration of interests}

The authors declare no competing interests.

\section{Contribution of authors}

VR was in charge of the patient and wrote the first draft of the article; JR, VLM, PB, and DM contributed to the patient's management and corrected the article's drafts. AM suggested using etanercept as a salvage treatment, closely supervised the writing and the various drafts of the article. LL agreed to dispense etanercept and corrected the final version of the article. VF is the patient's physician and corrected the final version of the article. 
A 38-year-old homeless man was hospitalized in our infectious disease department for odynophagia and a progressive 26-kg weight loss over the previous two months. His medical history was notable for heroin addiction. Upon arrival fever $\left(38.1^{\circ} \mathrm{C}\right)$ and cachexia were observed with a body mass index measured at $16 \mathrm{~kg} / \mathrm{m}^{2}$. Several deep, painful, round, and well-marked ulcerations were observed on the tongue, palate, and inner cheeks (Figure 1). No genital lesions were observed.

An HIV serology was positive with a complete Western Blot. Plasma HIV-1 viral load was measured at $10^{6}$ copies $/ \mathrm{ml}$, and lymphocyte T CD4 count at 5/ $\mathrm{mm}^{3}$. EBV, CMV, toxoplasmosis, and B19 parvovirus serologies were consistent with previous immunization. Syphilis serology was negative. Plasma HHV6, CMV, EBV, and leishmaniasis PCR tests were negative. HSV-1 PCR on mouth ulcer sampling was initially positive, and CMV PCR was negative. Treatment with a 7-day course of valaciclovir ( $1 \mathrm{~g}$ thrice daily), followed by a 4-day course of intravenous acyclovir ( $1 \mathrm{~g}$ thrice daily) and a 6-day full-dose course of foscarnet with a 21-day fluconazole therapy (100 mg daily), as well as antiretroviral combination introduction on Day 6 with emtricitabine, tenofovir, and dolutegravir were of no clinical efficacy, despite negative HSV-1 PCR on mouth sample controls. A biopsy procedure revealed deep necrosis in rare muscle fibers, and a polymorph, non-specific inflammation, with no signs of viral cytotoxicity or malignancy. A diagnosis of HIV-related severe aphthous stomatitis was made. Mycobacterium smear and culture were both negative.

A 10-day systemic corticosteroid therapy (oral prednisone, $1 \mathrm{mg} / \mathrm{kg}$ ), initiated on Day 21 resulted in frank worsening of the aphthous lesions. Oral administration of food, antiretroviral therapy (switch to soluble lamivudine, tenofovir, and etravirine), and cotrimoxazole became impossible, despite intravenous morphine therapy. On Day 35 a jejunostomy procedure was performed. By analogy with reported treatment of severe HIVassociated aphthous lesions with thalidomide [1] and given the pathophysiological importance of TNF- $\alpha$ [2], a subcutaneous treatment with the anti-TNF- $\alpha$ etanercept ( $25 \mathrm{mg}$ twice weekly) was initiated on Day 50. Symptoms and aphthous ulcers improved considerably within three days. On Day 85, after a 35-day course of etanercept, thalidomide was introduced at $100 \mathrm{mg}$ daily. On Day 180 the patient was well with no remaining aphthous ulcers. He remained HIV-viral load undetectable and had increased lymphocyte T CD4 level (189 cells $\left./ \mathrm{mm}^{3}\right)$. 


\section{Discussion}

Aphthous ulcers are round and well-marked ulcerations, with a hard and clean core, covered with a yellowish pseudo-membrane and surrounded by an erythematous halo. They are painful and can, in severe cases, prevent swallowing and phonation. They are usually found on non-keratinized epithelia of the oropharyngeal, genital, and/or anorectal mucosa [3]. Lesions are made of sub-epithelial mononuclear infiltrates, associated with basal keratinocytes, with neutrophils adjacent to the lesions. TNF- $\alpha$ is central to the pathophysiology [2]. There seems to be an increased incidence and severity of aphthous lesions in HIV-infected patients, particularly in subjects with low lymphocyte T CD4 depletion levels [3]. Persistent and large ulcers may require biopsy to exclude lymphoma, deep fungal or mycobacterial infections, atypical herpes simplex lesions, and cytomegalovirus disease.

The first-line treatment of moderate to severe aphthous ulcers is a systemic corticosteroid therapy (70\% of effectiveness according to a study [4]). Thalidomide $100 \mathrm{mg}$ daily is considered the most effective second-line treatment of severe cases or in case of treatment failure [1], due to its immuno-modulation and anti-TNF- $\alpha$ action. It is mandatory to monitor the hemogram, neurological signs, and to prescribe an effective birth control method. The impossibility to use oral thalidomide in our patient led us to discuss subcutaneous anti-TNF- $\alpha$ therapies. The spectacular efficacy of anti TNF- $\alpha$ in severe aphthous ulcers has been previously described in Behcet's and Crohn's diseases with etanercept $[5,6,7]$, but only in the general population. The choice of etanercept in our case was justified by its low reported rate of infections in the general population and its shorter half-life in case of adverse events [8]. Several cases with safe use of subcutaneous anti-TNF- $\alpha$ in HIV-infected patients presenting with other conditions, including life-threatening immune reconstitution inflammatory syndrome, have also been reported $[9,10]$.

The continuous worsening of our patient's lesions prior to treatment initiation and the spectacular improvement of the lesions after introduction of etanercept suggested direct involvement of the drug in the clinical response. To our knowledge this is the first reported case of an HIV-infected patient presenting with severe and refractory aphthous ulcers treated with subcutaneous anti-TNF- $\alpha$. Further reports could confirm etanercept response in HIV-related aphthous ulcers, particularly in salvage cases. 


\section{References}

1. Paterson DL, Georghiou PR, Allworth AM, Kemp RJ. Thalidomide as treatment of refractory aphthous ulceration related to human immunodeficiency virus infection. Clin Infect Dis. 1995;20(2):250-254.

2. Natah SS, Hayrinen-Immonen R, Hietanen J, Malmstrom $M$, Konttinen $\mathrm{YT}$. Immunolocalization of tumor necrosis factor-alpha expressing cells in recurrent aphthous ulcer lesions (RAU). J Oral Pathol Med. 2000;29(1):19-25.

3. MacPhail LA, Greenspan D, Feigal DW, Lennette ET, Greenspan JS. Recurrent aphthous ulcers in association with HIV infection. Description of ulcer types and analysis of T-lymphocyte subsets. Oral Surg Oral Med Oral Pathol. 1991;71(6):678683.

4. Femiano F, Buonaiuto C, Gombos F, Lanza A, Cirillo N. Pilot study on recurrent aphthous stomatitis (RAS): a randomized placebo-controlled trial for the comparative therapeutic effects of systemic prednisone and systemic montelukast in subjects unresponsive to topical therapy. Oral Surg Oral Med Oral Pathol Oral Radiol Endod. 2010;109(3):402-407.

5. Melikoglu M, Fresko I, Mat C, et al. Short-term trial of etanercept in Behcet's disease: a double blind, placebo controlled study. J Rheumatol. 2005;32(1):98-105.

6. Hasan A, Patel H, Saleh H, Youngberg G, Litchfield J, Krishnaswamy G. Remission of severe aphthous stomatitis of celiac disease with etanercept. Clin Mol Allergy. 2013;11(1):6.

7. Robinson ND, Guitart J. Recalcitrant, recurrent aphthous stomatitis treated with etanercept. Arch Dermatol. 2003;139(10):1259-1262.

8. Takeuchi T, Miyasaka N, Kawai S, et al. Pharmacokinetics, efficacy and safety profiles of etanercept monotherapy in Japanese patients with rheumatoid arthritis: review of seven clinical trials. Mod Rheumatol. 2015;25(2):173-186.

9. De Simone C, Perino F, Caldarola G, D'Agostino M, Peris K. Treatment of psoriasis with etanercept in immunocompromised patients: Two case reports. J Int Med Res. 2016;44(1 suppl):67-71. 
10. Richaud C, Ghosn J, Amazzough K, Poiree S, Lortholary O. Anti-tumor necrosis factor monoclonal antibody for steroid-dependent TB-IRIS in AIDS. AIDS. 2015;29(9):11171119. 
Figure 1. Mouth aphthous ulcers before (above) and after 15 days of etanercept treatment (below).

Figure 1. Aphtes à l'initiation (au-dessus) et après 15 jours de traitement par étanercept (endessous).

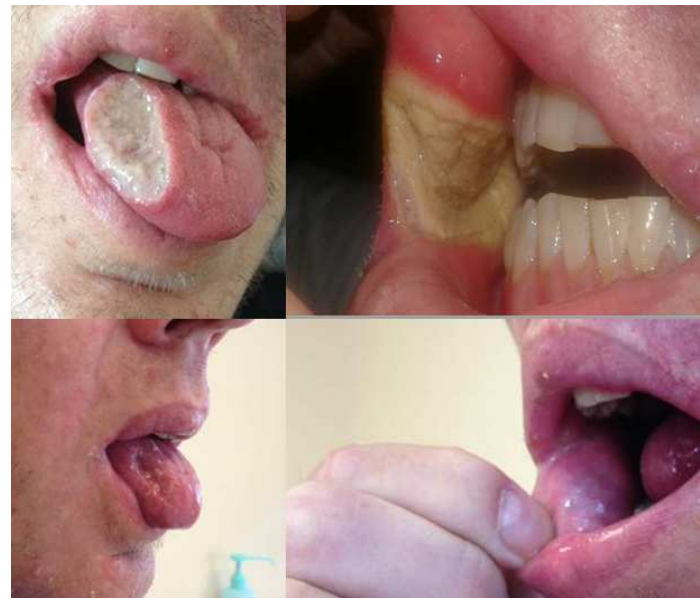

